\title{
WITTGENSTEIN E A TRADIÇÃO FILOSÓFICA: ASPECTOS METODOLÓGICOS
}

\author{
Gilberto Ferreira de Souza ${ }^{1}$ \\ Universidade Estadual de Campinas (UNICAMP) \\ (D) https://orcid.org/0000-0002-2378-5563
}

\begin{abstract}
RESUMO:
Uma das principais preocupações de Ludwig Wittgenstein, presente já desde as suas primeiras observações, é a autonomia do pensamento próprio. Nosso objetivo neste texto é indicar alguns aspectos metodológicos do diagnóstico e da crítica que o filósofo vienense opera em relação à tradição filosófica ocidental com vistas a possibilitar a obtenção de resultados seguros e pacíficos no universo polêmico da filosofia. Para tanto, indicaremos a importância de recuperar o papel que a tradição filosófica desempenha para o pensamento próprio, assim como a importância de conscientizar-se de que a principal dificuldade da filosofia é estar diante dos conceitos sem préconceitos. Além disso, ressaltaremos a necessidade de superação das dificuldades humanas como a da vontade mostrando na filosofia de Wittgenstein a presença da atividade destruidora dos vícios, adornos e ídolos herdados bem como a sua importância para a averiguação das condições lingüísticas do próprio pensar.
\end{abstract}

PALAVRAS-CHAVE: Tradição filosófica; Wittgenstein; Método; Terapia.

\section{WITTGENSTEIN AND THE PHILOSOPHICAL TRADITION: METHODOLOGICAL ASPECTS}

\begin{abstract}
:
One of the main concerns of Ludwig Wittgenstein, already present from his first observations is the autonomy of his own thought. Our objective in this text is to indicate some methodological aspects of the diagnosis and criticism that the Viennese philosopher operates in relation to the Western philosophical tradition with a view to obtaining safe and peaceful results in the controversial universe of philosophy. To do so, we will indicate the importance of recovering the role that the philosophical tradition plays for its own thought, as well as the importance of becoming aware that the main
\end{abstract}

\footnotetext{
${ }^{1}$ Doutor em Filosofia pela Universidade Estadual de Campinas (UNICAMP), Campinas Brasil. E-mail: gilbertosouza_2005@yahoo.com.br Wittgenstein e a tradição filosófica: aspectos metodológicos - Gilberto Ferreira de Souza

Griot : Revista de Filosofia, Amargosa, Bahia - Brasil, v.15, n.1, p.204-232, junho/2017 
difficulty of philosophy is to be faced with concepts without preconceptions. In addition, we will emphasize the need to overcome human difficulties like that of the will showing in the philosophy of Wittgenstein the presence of the destructive activity of inherited vices, adornments and idols as well as their importance for the investigation of the linguistic conditions of thinking itself.

KEYWORDS: Philosophical tradition; Wittgenstein; Method; Therapy.

\section{Introdução}

Como caracterizar a relação de Wittgenstein para com a tradição filosófica? Qual é o papel que a tradição filosófica desempenha no pensamento do filósofo vienense? Poderia dizer que Wittgenstein construiu algum tipo de resistência motivado pelo conhecimento apurado que se tinha dela? Teria tal conhecimento revelado que e como a tradição sofre de uma doença e a resistência funcionaria como um meio de desintoxicação ou prevenção contra qualquer possibilidade de contágio? Mas como poderia ser algo dessa natureza se o próprio Wittgenstein, como veremos, reconhece dispor de pouca leitura da tradição filosófica? Então, se Wittgenstein não dispunha de algum tipo de conhecimento aprofundado da tradição, o distanciamento que recomenda em relação a ela parece ser resultado de uma preocupação em proteger a Filosofia ou o filosofar autêntico em relação a toda e qualquer forma de má influência.

O que parece ocupar o centro de toda preocupação de Wittgenstein para com a filosofia é preservar e elevar ao máximo a autonomia do próprio pensamento, características fundamentais de quem se dispõe a filosofar ${ }^{2}$. Desta forma, mesmo que o esforço levado a cabo pelo pensamento possa trilhar por caminhos que conduzem a resultados que não fazem mais que repetir os resultados outrora alcançados, estes devem emergir em um terreno livre de intromissões alheias, assim como de um confronto genuíno e original com os problemas atuais.

Mas seria possível estar diante dos problemas sem as intromissões alheias? Ou seja, de forma completamente original, sem qualquer saber constituído ou qualquer pré-concepção acerca deles? Caso a resposta seja positiva, o sujeito estaria, assim, diante de algo como um começo absoluto, livre de qualquer coisa que possa condicionar o confronto com os próprios problemas.

\footnotetext{
2 Embora não se tenha a indicação explícita na própria obra de Wittgenstein, esta interpretação nos remete ao empreendimento crítico levado a cabo por Kant, particularmente à noção de "pensar por si mesmo" ou de "esclarecimento" ('Aufklärung'). Ver, por exemplo, o texto do próprio Kant $O$ que é esclarecimento? (KANT, 1974, p. 110117).
} 
A presente exposição das observações metodológicas em torno da relação de Wittgenstein com a tradição filosófica ocidental será organizada em alguns sub-itens, a saber: a recuperação do papel que a tradição filosófica desempenha para o pensamento próprio; a tomada de consciência de que a principal dificuldade da filosofia é estar diante dos conceitos sem pré-conceitos; a superação das dificuldades humanas como as resistências da vontade; a efetivação da atividade destruidora dos vícios, adornos e ídolos herdados; e a averiguação das condições lingüísticas do pensar próprio. Vejamos cada um deles.

\section{0 papel da tradição}

No ano de 1947, Wittgenstein declara, de forma franca e direta, o fato de ter lido apenas alguns textos de autores consagrados pela história do pensamento filosófico ocidental e de ter sido influenciado por eles. No primeiro texto publicado em 1913 e frequentemente negligenciado pelos pesquisadores, The Science of Logic (TSL), ${ }^{3}$ Wittgenstein faz um pronunciamento sobre a questão e abre um confronto contundente com relação ao conhecimento herdado da tradição filosófica: "Em nenhum ramo do conhecimento um autor pode ignorar os resultados de uma investigação honesta com tanta impunidade como em Filosofia e Lógica." (TSL, 853, 1913, p. 351)

Esta passagem detecta e sublinha, entre outras coisas, que em nenhum ramo do conhecimento alguém está tão sozinho e entregue às suas próprias responsabilidades como em filosofia. Segundo Wittgenstein, há uma significativa ignorância e ela está coberta por uma total "impunidade".

A mesma questão reaparece em 1921 no prefácio do TLP, redesenhado, agora, de outro modo. Vejamos:

Não quero julgar até que ponto os meus esforços coincidem com os de outros filósofos. Mais: o que aqui escrevi não tem, em pormenor, absolutamente nenhuma pretensão de novidade; e, por isso, também não indico quaisquer fontes, porque me é indiferente se aquilo que eu pensei um outro o pensou já antes de mim. Quero apenas mencionar isto, que devo uma grande parte do estímulo para os meus pensamentos às grandiosas obras de Frege e aos trabalhos do meu amigo, o senhor Bertrand Russell. (MS 204, ii = Cf. TLP, Prefácio, p. 131) ${ }^{4}$

\footnotetext{
${ }^{3}$ As citações das obras de Wittgenstein ao longo do artigo serão referenciadas pelas siglas acompanhadas do número da página ou do parágrafo referente. E as referências aos Manuscritos (MS) e Datiloscritos (TS) citados são do Nachlass (WN) conforme "Lista de Abreviaturas" apresentadas no final do artigo. Todas as traduções são de minha responsabilidade.

${ }^{4}$ De acordo com Wittgenstein, um pensador tem de desbravar caminho por si mesmo e, se ele ao empreender essa tarefa encontra apenas aquilo que outros já pensaram e disseram,
} 
Este texto é relevante por diversos motivos. Por um lado, Wittgenstein não formula propriamente uma ignorância ou um desconhecimento da tradição filosófica. Mas, por outro lado, proclama uma total indiferença em relação à coincidência que possa ou não haver entre o que ele pensa e o que já foi anteriormente pensado por outrem, indiferença essa que aparece associada à negação de qualquer pretensão de novidade, vista que a mesma não diminui em nada a sua pertinência e não tem qualquer importância.

Wittgenstein, no entanto, limita-se a declarar a indiferença em questão, e deixa inteiramente em aberto em que medida conhece ou não outros pensadores, com exceção de seus contemporâneos como Frege e Russell, e fica também inteiramente em aberto até que ponto outros pensadores tiveram ou não algum papel na gênese dos seus pensamentos relacionados à Filosofia e ao seu método, à excessão da expressa alusão aos mencionados aqui e ao longo dos demais textos.

Além disso, fica também em aberto qual é e em que consiste a origem da indiferença manifestadamente declarada por Wittgenstein em relação ao pensamento alheio, qual é a perspectiva adotada, e quais as razões que a motivam e justificam. Desde já, uma sugestão que se pode adiantar é que o contato e o conhecimento com os pensadores alheios mencionados não resultou em uma total indiferença com relação às perspectivas filosóficas e metodológicas adotadas por Wittgenstein. Pelo contrário, nas palavras do próprio Wittgenstein, revelou-se ser "estimulante".

Outra passagem relacionada ao conhecimento ou ignorância de Wittgenstein para com a tradição filosófica encontra-se formulada nos TB 1914-16: "Não ter preocupação com aquilo que já alguma vez se escreveu! Começar a pensar sempre do princípio, como se ainda não tivesse acontecido absolutamente nada." (TB 1914-16, de 15/11/14, p. 30)

Esta passagem apresenta, de forma clara, dois aspectos principais: por um lado, sugere a ideia de uma exclusão total de qualquer pensamento advindo de outrem para apresentar-se a partir de um começo inteiramente

variações próximas ou remotas de pensamentos consagrados ou se, pelo contrário, elabora um novo edifício desconhecido para a tradição, isso não o preocupa.

5 Wittgenstein cita nominalmente vários filósofos e pensadores ao longo de suas observações, e eles estão visíveis à superfície do próprio texto. Isto, porém, por si só não funciona como prova de que eles serviram de estímulo, pois não fica claro qual seja o papel que desempenharam quanto à sua gênese. Assim, alguns são citados diretamente como Bertrand Russell, Gottlob Frege, Guilherme de Ockham, Fritz Mauthner, Heinrich Hertz, Charles Darwin, Norman Whitehead, Edward Moore, Isaac Newton e Immanuel Kant, entre tantos outros. Todavia, em diversas passagens são evidentes as referências indiretas a teses ou autores que não são citados nominalmente, entre eles, Die Prinzipen de Mechanik de Heinrich Hertz, Die Goldkinder, dos irmãos Jacob e Wilhelm Grimm, Die Welt als Wille und Vorstellung de Arthur Schopenhauer. 
novo, como se antes não tivesse havido absolutamente nada que o pudesse influenciar; por outro lado, indica uma interrupção com algo cuja origem é a tradição, não apenas por uma mera indiferença em relação àquilo que já foi pensado por outros, mas como tendo justamente o caráter de um preceito metodológico. Todavia, a questão continua em aberto, pois há a enunciação de um preceito metodológico sem adiantar os seus motivos originários.

Outra observação composta em 1929 e publicada em VB nos põe um passo à frente na questão para tentar entender os motivos do preceito metodológico enunciado por Wittgenstein, que diz assim: "É preciso atravessar todas as manhãs, novamente, o cascalho morto para se chegar ao núcleo quente e vivo." (MS, 107, 82 = Cf. VB, 1929, p. 4)

Esta passagem expressa uma contraposição entre algo descrito como "morto" e algo descrito como "vivo". O vivo em causa nesta questão é apresentado como inerente ou imediato. Ora, tal contraposição é relevante, entre outras razões, porque pode ser aplicada na própria relação que se pode fazer com os enunciados de outrem. Kant, por exemplo, pôs em causa esta questão do pensamento livre e autônomo, quando a descreveu como um elemento decisivo para a Doutrina Transcendental do Método, e concluiu dizendo que "o verdadeiro filósofo, enquanto pensa por si, tem de fazer um uso livre e próprio da razão, e não um uso servil e imitador da mesma".

Se abstraio de todo o conteúdo de conhecimento objetivamente considerado, então todo o conhecimento é, subjetivamente, ou histórico ou racional. O conhecimento histórico é o cognitio ex datis e o racional é o cognitio ex principiis. Seja qual for a proveniência a partir da qual um conhecimento originariamente se dê, esse conhecimento é, naquele que o possui, histórico, se só o conhece no grau e na medida em que lhe foi dado do exterior, quer este conhecimento lhe tenha sido dado por experiência imediata ou por narração ou também por ensinamento (de conhecimentos gerais). Por isso, aquele que aprendeu propriamente um sistema filosófico, p. ex. o de Wollf, mesmo que tivesse na cabeça todos os princípios, definições e todas as demonstrações juntamente com a divisão de todo o corpo doutrinário e pudesse contar tudo pelos dedos não teria, ainda assim, senão o conhecimento histórico completo da filosofia de Wollf; [...] Ele compreendeu bem e o fixou, isto é, aprendeu bem e é assim a máscara de um ser humano vivo. (KANT, 1781 [2003], A835-836; B863-864)

Se for mesmo esta questão que está em causa no pensamento de Wittgenstein, a perspectiva que ele indica parece corresponder a uma atitude muito peculiar que não implica nem em uma condenação total da tradição filosófica nem em um reconhecimento de qualquer papel relevante da mesma em relação ao pensamento atual e/ou próprio de alguém. E isto acontece porque, neste caso, nada impede que os pensamentos de outrem, passados ou não, tenham validade e relevância em si mesmo. O valor só é 
dado ou recuperado por alguém a partir do momento em que re-constrói um pensamento de forma autônoma como quem "aprendeu a pensar por si mesmo" como se estivesse desenvolvendo uma parte integrante do seu ser orgânico: "Como se aprende a verdade por meio do pensamento? Tal como se aprende melhor a ver um rosto desenhando-o." (MS 109, $68=$ Cf. Z, $\S 255)^{6}$

O conjunto de duas outras observações de Wittgenstein em VB pode ser aplicado em nossa reflexão permitindo compreender melhor o seu estado. A primeira observação, diz o seguinte: "Uma vez disse, e talvez com razão, que a cultura antiga se tornará um montão de destroços e, por fim, um montão de cinzas, mas sobre as cinzas pairarão espíritos." (MS 107, $230=$ Cf. VB, p. 5). E a segunda observação diz assim: "As obras dos grandes mestres são sóis que se erguem e se põem à nossa volta. De modo que virá, de novo, o tempo para cada grande obra que agora está caída em declínio." (MS 111, 194 = Cf. VB, p. 23)

Segundo a primeira passagem, o montão de destroços a que foi reduzida a cultura antiga ultrapassa a aparência de simples monte de cinzas ou de algo inteiramente morto, pois tem o privilégio de que sobre eles pairam espíritos. Já a segunda observação apresenta as obras consideradas clássicas como que sóis que se movimentam constantemente à nossa volta. Se estas duas observações referem-se a algo que ao mesmo tempo pertence ao passado, mas que também parece estar em condições de alimentar o pensamento próprio de alguém, outra observação da mesma obra sugere que não é bem simples assim:

Cada artista foi influenciado por outros e mostra os vestígios dessa influência nas suas obras; mas, aquilo que ele significa para nós é, sem dúvida, a sua personalidade. Aquilo que tem origem nos outros pode ser somente cascas de ovo. Que elas estejam aí é algo que podemos tratar indulgentemente, mas elas não constituirão o nosso alimento espiritual. (MS 111, $194=$ Cf. VB, p. 23)

E a mesma mensagem é ainda mais reforçada numa outra observação: "Ninguém pode pensar um pensamento por mim, tal como ninguém pode pôr o chapéu por mim, senão eu." (MS 107, $100=\mathrm{Cf}$. VB, p. 4; MS 148, 31v-32r = Cf. LPE, 1936, p. 10)

6 Encontram-se também outros enunciados dispersos pelas várias observações de Wittgenstein que remetem de uma forma explícita para o cerne do problema aqui referido. Veja-se, por exemplo, como a sua exposição na Philosophische Grammatik se aproxima da forma da exposição kantiana: "Podíamos dizer: em todos os casos com a palavra 'pensamento' queremos dizer aquilo que está vivo na frase. Aquilo sem o qual ela está morta, sem o qual é uma simples sequência de sons ou uma sequência de caracteres escritos." (MS 114, 190 = Cf. PG, §65; MS 114, 190 = Cf. Z, §143). Ver também: MS 146, 49; MS 156b, 5r; MS 183, 111. 
Então, o conjunto destas observações acima elencadas nos permite afirmar que para Wittgenstein o pensamento de cada ser humano, por mais que tenha acontecido no passado e se sucede com contribuições individuais, a grande reunião, como queria Aristóteles ${ }^{7}$ ou $\mathrm{Kant}^{8}$ só pode acontecer cada vez de novo a partir do zero.

E Wittgenstein vai ainda mais longe, quando enfatiza que os enunciados de outrem são uma pequena e secundária parte do meu contato com o mundo: Se por um lado eles integram o horizonte desse contato em que nasceram e tinham vida, mas que estão agora desligados, por outro lado só podem voltar a ganhá-la se, por assim dizer, nascerem de novo em um terreno completamente diferente desta outra experiência do mundo em cujo âmbito aparecem transplantados. Isso é o que Wittgenstein parece sugerir, na seguinte observação: "O filósofo não é um cidadão de uma comunidade de idéias. É justamente isto que faz dele um filósofo." (MS 112, p. 72r = Cf. $\mathrm{Z}, \S 455)^{9}$

E, ainda, em outra passagem, ele expressa a relutância em expor publicamente as suas idéias a certo tipo de público denominado de "filósofos jornalistas" (philosophischen journalisten):

É com relutâcia que ofereço este livro ao público. As mãos em que ele vai chegar não são unicamente aquelas que eu aconselhavelmente gostaria de imaginar. Possa ser, assim o desejo, tão logo esquecido pelos jornalistas filosófos e assim talvez um melhor tipo de leitores o manterá. (MS 136, 1948, $81 \mathrm{a}=$ Cf. VB, p. 66)

\footnotetext{
${ }^{7}$ O pensamento de Aristóteles traduz-se nas seguintes palavras: "A investigação da verdade é em um sentido difícil e em outro fácil. Sinal disso é o fato de ninguém conseguir alcançála devidamente, nem todos a falharmos por completo, antes suceder que cada um diz algo acerca da natureza; e é nada ou é pouco o que cada um contribui para essa investigação, mas a partir da conjugação de todos, forma-se algo grandioso.” (ARISTÓTELES, 1990, Livro II, 993a. 30-993b.4)

${ }^{8}$ Para Kant, “As cabeças que pensam fazem parte de um mundo de eruditos que está em ligação ininterrupta (mesmo que alguns séculos fazem interpor um sonho/sono). Deste modo, o mundo antigo faz parte do jovem mundo dos eruditos ou do mundo que pensa, os novos fazem parte do mundo antigo, bem entendido, quando tiram proveito das intelecções do mundo mais jovem." (KANT, 1488, AA. Vol. XV, p. 632)

${ }^{9}$ Há várias passagens da obra de Wittgenstein que contribuem decisivamente para o esclarecimento desta forma de isolamento; entre elas algumas que nos parecem incontornáveis são as seguintes: TS 227b, 140-1 = Cf. PU, §194, pp. 341-2; MS 136, 18b = Cf. BPP, II, §87, p. 235; MS 175, 64v-65r... = Cf. ÜG, §387, p. 196; MS 109, 68 = Cf. Z, $\S 255$; MS 110, $18=$ Cf. VB, p. 12; MS 134, $143=$ Cf. VB, p. 69; MS, 112, 72r = Cf. VB, p. 75 .
} 


\section{A principal dificuldade da filosofia}

Parece haver outro motivo, não menos importante, que tem a ver com um ataque de Wittgenstein à tradição e a compreensão desta como um entrave, um obstáculo, ou um elemento viciante o qual é necessário extirpar. Uma observação escrita em código no ano de 1947 (MS 135) nos fornece uma clara indicação neste sentido: "Por pouca filosofia que eu tenha lido, não li certamente a menos, mas antes a mais. Vejo isto quando leio um livro filosófico: ele não melhora os meus pensamentos, torna-os piores." (MS 135, de 27/7/1947, p. 101) ${ }^{10}$

Esta observação revela, de forma explícita, que não se trata apenas e tão somente de uma questão de não poder ter acesso à experiência alheia e à vida em que os enunciados filosóficos emergem de forma natural, mas sim de um efeito prejudicial inerente a qualquer recorrência a enunciados alheios que possa piorar o pensamento próprio. Por pouco que tenha sido o contato que teve com a tradição, Wittgenstein não o entende como um defeito ou falta, mas como um excesso, isso porque ao invés desse contato com os enunciados de outrem desempenhar qualquer função de estimulador positivo, o efeito torna-se precisamente o oposto.

Wittgenstein já havia apresentado algo similar em Z, por exemplo, onde disse o seguinte:

\footnotetext{
É muito difícil descrever rumos de pensamento onde já existem muitos trilhos - teus ou de outros - e não entrar em um dos carris já mais do que percorridos. É difícil desviarmo-nos, um pouco que seja, de um velho trilho de pensamento. (TS 221, $240=$ Cf. Z, §349)
}

O filósofo vienense parece não ter dúvidas de que a chave do pensamento filosófico autônomo se encontra no abandono dos caminhos trilhados pela tradição através de outra trilha que permita desviar dos seus terrenos. Trata-se de algo mais do que o simples fato de ter de começar tudo outra vez do início fazendo pouco caso da tradição. O sentido, que parece ser bem diferente, é revelado em duas outras passagens similares no

\footnotetext{
${ }^{10}$ Em carta enviada a G. H. Von Wright, Wittgenstein, embora de maneira ligeiramente diferente, manifesta esta mesma relutância: "Fico contente por vir lecionar aqui e eu sei que se assistisse às suas aulas podia aprender uma quantidade de coisas. Apesar disso, eu não irei - pela única razão de que, para viver e trabalhar, tenho de não autorizar nenhuma importação de bens estrangeiros (i. e., bens filosóficos) para o meu espírito. Pela mesma razão não li o seu livro, embora esteja convencido da sua excelência." (Cf. WCLD - 361: 50, LW-GHW, carta de 21/2/1947).
} 
contexto da Filosofia da Psicologia. A primeira diz: "Nada é mais difícil do que estar diante dos conceitos sem preconceitos. (E esta é a dificuldade principal da filosofia.)" (MS136, 18b = Cf. BPP II, §87, p. 235). E a segunda: “(...) Nada mais difícil do que considerar os conceitos sem préconceitos. Porque o pré-conceito é [uma forma de] entendimento. E renunciar a ele quando precisamente tanta coisa importante para nós reside aí." (MS 137, 77b = Cf. LSPP I, §12) ${ }^{11}$

A dificuldade a que Wittgenstein se refere parece ser de mão dupla. Por um lado é difícil criar uma distância própria em relação ao pré-conceito e abrir mão dele, por outro lado este aspecto não nasce apenas de qualquer coisa como um efeito da passividade. De fato, na origem do preconceito (que já é um conceito formado), há uma imagem de compreensão permitindo que nos sintamos "situados", "orientados" em relação a algo. É uma espécie de apego da nossa parte, e há ou deve haver uma relutância em abandoná-lo, em sair dessa situação.

E além da dificuldade deste "êxodo" ou abandono de onde nos encontramos até acomodados, há também outra, aquela que afeta a abertura de uma perspectiva como alternativa, ou seja, há uma barreira que deve ser vencida para que seja possível passar a ver e considerar as coisas a partir de outro ângulo. $\mathrm{O}$ resultado disso é que a partir de um determinado momento consigamos ver algo para o qual, até então, estávamos como que "cegos".

Wittgenstein também retrata nas suas BGM o sentido desse aspecto apontado. Alí ele ressalta que a resolução de determinados problemas filosóficos requer uma comparação entre as perspectivas possíveis (MS 124, pp. 67-8 = Cf. BGM, V, §12, p. 270). Aliás, uma das propostas recorrentes nas obras de Wittgenstein é olhar os problemas filosóficos a partir de uma perspectiva inédita que muitas vezes procura solução na fértil imaginação de situações quase sempre bizarras e extravagantes com relação às propostas da filosofia tradicional. ${ }^{12}$

Um primeiro elemento que se precisa considerar quanto a esta observação é que ela diz respeito a alguns problemas filosóficos e não pode ser formulada com o objetivo de aplicar, de antemão, a todos os problemas.

\footnotetext{
${ }^{11}$ O ponto de vista "sem preconceitos", se assim é possível falar uma vez que um ponto de vista supõe e significa vista de um ponto, aqui referido, e o ponto de vista infantil podem compartilhar de um aspecto comum, a saber, a matriz originária da linguagem por meio da qual dirigem-se às coisas para nomeá-las com o seu nome próprio. $\mathrm{O}$ ponto de vista infantil, dotado da capacidade de inocência e de batizar as coisas, habitualmente diverge e choca com a maneira adulta de lidar com as coisas de forma protegida e embrulhada por uma tradição ou moda. O ponto de vista livre de todos os preconceitos e constrangimentos, por sua vez, sem o conhecimento rigoroso acerca do que são as coisas, seria o único capaz de atingir as coisas em sua concretude e realidade. Veja, por exemplo, a passagem 327-330 da LSPP I.

${ }^{12}$ Entre os vários exemplos desta proposta de Wittgenstein contidos nas suas observações filosóficas, indicamos dois das BGM: MS 222, 7-8 = Cf. BGM, I, §5, p. 38 e MS 117, 195 $=$ Cf. BGM, III, §76, p. 201.
} 
Todavia, não se pode excluir a possibilidade de aplicação a um âmbito mais vasto e, se isto acontecer, estaria a traduzir a atitude de Wittgenstein com relação a todos eles. Em todo o caso, a observação põe em relevo a necessidade de um ponto de vista ou de um ângulo novo que seja uma oportunidade de se escapar à excentricidade com relação a todas as formas de perspectivas já constituídas que possam levar a confusão. Assim, para a resolução de cada problema filosófico há a indispensável necessidade de variação, de um novo ponto de vista assemelhado a uma "revolução copernicana".

Por outro lado, a observação das BGM indica a forma pela qual se deve produzir esta variação de ângulo ou de ponto de vista talvez nunca antes considerado: ela passa por uma comparação entre coisas que nunca ocorreu a ninguém comparar. Quer dizer, ela passa pelo estabelecimento de casos ou ligações intermediárias (Zwischengliedern) e confrontos entre as mesmas que já estão, de algum modo, presentes no horizonte, ainda que não ligadas umas com as outras. ${ }^{13}$

Por fim, as denominadas "revoluções copernicanas" pelas quais deve passar a compreensão dos problemas filosóficos não passam tanto pela descoberta de novos fenômenos, mas pelo estabelecimento e consideração dos conceitos ou das relações entre diferentes elementos que podem, desde muito tempo, estar presentes no horizonte aberto ao conhecimento.

Outra passagem de VB, vai também na mesma direção. Alí Wittgenstein se refere a uma ultrapassagem dos problemas filosóficos e conecta essa ultrapassagem ao desenvolvimento de concepções "ainda mais loucas" do que as dos filósofos: "Só quando se pensa ainda mais loucamente do que os filósofos, é possível solucionar os seus problemas" (MS 137, p. $102 \mathrm{a}=$ Cf. VB, p. 86).

Embora nesta observação Wittgenstein pareça associar os problemas filosóficos a um tipo de loucura, o que ele faz é situar a sua solução ou um retorno à saúde que os filósofos perderam e apresentar como chave ou como remédio o desenvolvimento de algo similar a uma superloucura para, só assim, obter efeito de anular ou compensar. ${ }^{14}$

13 A noção de Zwischengliedern, casos ou ligações intermediárias, é um conceito
wittgensteinano usado como um instrumental, não apenas acessório, mas constitutivo da
investigação terapêutico-conceitual desenvolvida pelo filósofo a partir dos anos de 1930 .
Um dos objetivos das ligações intermediárias consiste em treinar o olhar para se chegar a
uma visão perspícua da diversidade dos usos dos conceitos. Este conceito ainda não
recebeu a devida importância por parte dos comentadores de Wittgenstein, no entanto é de
fundamental importância para a presente reflexão. Citamos algumas passagens dos
manuscritos de Wittgenstein em que encontramos o termo Zwischenglieder/
Zwischengliedern: MSS 106, 118,$119 ; 108,218 ; 109,224 ; 110,144,257 ; 114,148 ; 136$,
137 a; 140,$32 ; 142,107 ; 152,52 ; 157 b, 14 r ; 160,11 r ; 208,38 ;$ TSS 209,$90 ; 211,282,397 ;$
$212,1079,1144 ; 213,388 r, 417 ; 220,80 ; 227 a, 88 ; 227 b, 88 ; 237,82 ; 239,82$.
Não se trata simplesmente de uma rejeição, da parte de Wittgenstein, da tradição
mediante um "desvio filosófico" a partir da perspectiva considerada mais normal ou mais 
As observações feitas acima passam a ganhar nova luz se considerarmos um texto do BT que fundamenta a relação de rejeição da tradição em Wittgenstein em outra ordem de razões e parece contribuir de forma satisfatória para esclarecer os motivos pelos quais Wittgenstein se posiciona da forma que o fez nesta questão. O texto diz assim:

Ouve-se sempre a observação de que a filosofia não faz propriamente progresso, que os problemas filosóficos que já ocupavam os gregos nos ocupam ainda. Porém, aqueles que dizem isto não compreendem a razão por que é que tem de ser assim. A razão é que a nossa linguagem permaneceu igual a si e leva-nos sempre de novo, enganosamente, às mesmas perguntas. Enquanto houver um verbo 'ser' que parece funcionar como 'comer' e 'beber', enquanto houver os adjetivos 'idêntico', 'verdadeiro', 'falso', 'possível', enquanto se falar de um fluxo de tempo e de uma extensão de espaço, etc., os homens continuarão, sempre de novo, a tropeçar nas mesmas dificuldades enigmáticas e a olhar fixamente algo que nenhuma explicação parece ser capaz de remover. (TS 213, p. $424=$ Cf. BT, $\$ 90$, p. 312$)^{15}$

O primeiro aspecto que importa destacar nesta observação do BT diz respeito ao balanço que Wittgenstein faz de toda a tradição filosófica. Segundo ele, a tradição não produziu qualquer avanço, razão pela qual os problemas continuam a ser os mesmos desde a Grécia antiga. O que isto significa? Significa que os problemas atravessaram milênios de discussão e tentativas de resolução sem que se tenha registrado qualquer progresso ou resolução efetiva para eles. Para Wittgenstein, não basta verificar a situação simplesmente observando e tomando nota, deve-se compreender indo à origem dos problemas.

O segundo aspecto é o mais decisivo. De acordo com ele, a constância dos problemas, e também por isso, a ausência de qualquer efetiva solução para eles, tem origem na própria linguagem, nas suas estruturas e na forma como conseguiu atravessar os milênios mantendo e sustentando, como sendo fundamentais, tais estruturas. Estas mesmas estruturas fascinam

\footnotetext{
louca, mas aquilo que Wittgenstein quer ultrapassar é qualquer coisa como a "excentricidade" das concepções filosóficas. O que ele faz é ultrapassá-las por meio da própria radicalização da mesma de tal modo que o resultado dessa radicalização é, precisamente, a recondução, por via dela à perspectiva alternativa. Esta perspectiva alternativa assemelhada a uma superloucura tem agora a vantagem não de evitar qualquer tipo de reflexão filosófica, mas a de estar blindada contra a loucura filosófica. Essa blindagem não anula a possibilidade de qualquer recaída na confusão linguística, antes significa a aquisição de mecanismos de defesa que possibilitam resistir aos seus possíveis ressurgimentos.

${ }^{15}$ Pode-se ler, por exemplo, uma variante dessa observação em MS 111, 133-134 = Cf. VB, p. 22.
} 
de forma ilusória e, por essa via, desencadeiam todas as confusões da tradição filosófica.

Este segundo aspecto parece trazer à tona uma idéia propulsora de todo o pensamento filosófico de Wittgenstein que, como se verá, desempenha um papel central: a idéia de doença (Krankheit), a qual pode ser compreendida sob duas perspectivas principais. Por um lado, a linguagem e as suas estruturas não implicam, obrigatoriamente, em nada de doentio, servem aos diversos usos, o que são inteiramente saudáveis. Por outro lado, a linguagem e as suas estruturas envolvem a possibilidade ou tendência natural ao uso indevido. E a tradição, nesse sentido, enquanto baú de confusões quase que perpétuas, é vista como fruto desse uso incorreto da linguagem.

No centro da rejeição de Wittgenstein à tradição, tal como procuramos mostrar, parece estar, então, esta perspectiva, a saber, a recusa da tradição como um todo por um preceito metodológico, o qual podemos denominar de "ignorância voluntária". Esta não decorre nem de um conhecimento aprofundado da tradição e muito menos de um total desconhecimento da mesma, mas de uma atitude puramente metodológica. E a verdadeira base para tal rejeição será, então, uma compreensão da sua fonte, qual seja, da linguagem e das suas estruturas, que se dá mediante um diagnóstico desta linguagem e do seu uso indevido que funciona como origem e alimento das confusões filosóficas da tradição. Desta forma, a filosofia tradicional e os seus problemas são como tumores malígnos da doença na linguagem e compreendê-los assim é um dos preceitos metodológicos utilizados por Wittgenstein para a sua atitude com relação à tradição.

Uma perspectiva similar pode ser vista em outra observação, onde Wittgenstein escreveu o seguinte:

Os filósofos são muitas vezes como criança que começam por rabiscar traços ao acaso em um papel e, depois, perguntam ao adulto: 'o que é isto?'. O que se passou foi o seguinte: o adulto tinha desenhado várias vezes algo para a criança e tinha dito: 'isto é um homem', 'isto é uma casa', etc. E, agora, a criança também faz traços e pergunta: “agora o que é isto? (MS 112, $57-58=$ Cf. VB, p. 24) ${ }^{16}$

Os rabiscos da filosofia os quais a passagem se refere, são, de acordo com a nossa leitura, formas desviadas dos usos corretos e devidos da linguagem, então, usos incorretos e indevidos. E os dois aspectos constituem as possibilidades da linguagem.

A filosofia ocidental, ou melhor, as grandes questões da tradição filosófica ocidental nascem como que de "rabiscos" da linguagem e são,

\footnotetext{
${ }^{16}$ Uma variante desta passagem aparece em TS 213 , p. $430=$ Cf. BT, $\S 91$, p. 11, p. 315.
} 
assim, pseudodesenhos. Mas a perspectiva desenvolvida por Wittgenstein não está fundada em uma análise da tradição e sim em uma análise do fenômeno dos rabiscos, ou seja, do mau uso da linguagem e da forma como este fenômeno abre caminho para tantas confusões que têm origem nela.

O movimento de Wittgenstein em causa, nesta seção, tem, mais uma vez, certa similaridade com o movimento de Kant em seu empreendimento crítico: ao invés de analisarem os produtos finais, foca-se na fonte de onde tais produtos provêm, no caso de Wittgenstein, as estruturas da linguagem e as suas "doenças" ou "rabiscos." 17

\section{A ordem das dificuldades humanas}

O BT é uma coleção de observações reunidas por Wittgenstein entre os anos de 1932 e 1933. Mais do que qualquer outro texto deixado pelo autor, este tem a aparência linear de um livro acabado e completo, com títulos de capítulos e um sumário, e constitui a base do que seria lançado, com modificações, como PG. No capítulo intitulado "filosofia", especificamente nos parágrafos 86-92, Wittgenstein se ocupa com várias questões de cunho metodológico.

E uma das questões com a qual Wittgenstein se ocupa no BT, parágrafo 86, é a seguinte: o que significa dizer habitualmente que filosofar é algo difícil? Segundo Wittgenstein, diferentemente da concepção muito difundida pelo senso comum, entender questões filosóficas abtrusas não exige uma preparação especial. E a razão é simples, pois não se trata de alcançar um tipo de saber inacessível à maioria das pessoas, nem tão pouco apreender tal saber requer capacidades intelectuais fora do comum.

Da mesma forma também não existe, de antemão, nada de ordem intelectual que possa impedir a compreensão destas questões. A dificuldade a que Wittgenstein se refere é de outra ordem. Trata-se de uma resistência da vontade ou dos interesses próprios do sujeito, quase sempre despercebidos por uma análise superficial dos problemas envolvidos, mas que habitualmente interferem na compreensão e na representação do mundo mediante os enunciados filosóficos próprios ou de outrem. Em outras palavras, o contato filosófico com os fenômenos do mundo não acontece de uma forma neutra como se fosse obtido por meio de um aparelho cognitivo livre de toda e qualquer influência. A apreensão humana do mundo está contaminada por aspectos de foro sentimental e volitivo.

(Tolstoi: o significado (a significatividade) de um objeto reside na sua compreensibilidade geral. Isto é verdadeiro e falso. $\mathrm{O}$

\footnotetext{
${ }^{17}$ Pode-se ler criticamente as passagens inflexivas de Kant (Cf. KANT, 1781 (2003), A 8357-836, B 863-864) e de Wittgenstein (MS 109, pp. 204-209 = Cf. VB, Prefácio de 1930, pp. 8-9) acerca da investigação direta das próprias fontes ao invés de se limitar à consideração do seu produto.
} 
que torna o objeto dificilmente compreensível não é - quando ele é significativo, importante - que, para a sua compreensão, seja exigida qualquer instrução especial acerca de coisas abstrusas, mas antes a oposição entre o compreender do objeto e aquilo que a maioria das pessoas quer ver. Por isso, justamente aquilo que é o mais plausível pode tornar-se o mais difícil de compreender. O que se tem de superar não é uma dificuldade do entendimento, mas da vontade. (TS 213, $406=$ Cf. BT, §86, p. 300)

Portanto, o que aqui está em causa é, precisamente, um fenômeno pertencente exclusivamente à vontade e não ao intelecto que impede o ponto de vista de acatar pacificamente a mudança de olhar para um saber mais aguçado, mas que colide com os interesses imediatos do viver. Deve-se, portanto, superar as resistências da vontade em ver o que se quer.

Outra questão abordada no mesmo parágrafo refere-se à divisão dos problemas filosóficos em essenciais, universais e acidentais. Esta divisão não interessa à Wittgenstein. Em primeiro lugar porque tal divisão é cunhada a partir do universo científico e, para Wittgenstein, nada mais distante dos problemas científicos do que os filosóficos. Não há, portanto, uma classe de problemas de primeira ordem e outra de segunda ordem. Há apenas um gênero de problemas que interessa a Wittgenstein, o gênero filosófico, em particular porque uma atenção rigorosa dada à linguagem põe à vista um equívoco, a saber, a maneira como se levanta a questão resulta de uma falta de atenção em relação à lógica da linguagem. Isto é, a sua aparência de profundidade decorre de uma transgressão em relação à gramática da linguagem. A erradicação da classe de trangressões que está na origem das perguntas filosóficas tradicionais conduz, obviamente, à supressão da divisão acima apontada.

Dito de passagem, segundo a concepção antiga - por exemplo, a dos (grandes) filósofos ocidentais - existiam dois gêneros de problemas, no sentido científico, duas espécies de problemas [...]: problemas essenciais, grandes, universais e problemas inessenciais, como que acidentais. Em contrapartida, a nossa concepção é a de que não existe nenhum problema grande, essencial, no sentido da ciência. ((TS 213, $407=$ Cf. BT, §86, p. 301)

De forma resumida, neste parágrafo Wittgenstein rebate a abordagem a dois gêneros de problemas: em primeiro lugar, rebate a ideia de que filosofar seja uma tarefa difícil, acessível apenas a uma minoria especialmente dotada para levar a cabo essa atividade; em segundo lugar, combate a ideia de que exista mais do que uma classe de problemas em filosofia, designadamente, problemas essenciais e problemas acessórios.

O parágrafo 87 gira em torno de questões específicas da linguagem. Wittgenstein atribui à gramática da linguagem uma importância 
incontornável na solução dos problemas filosóficos. Para ele, a primeira etapa para solucionar uma questão filosófica consiste na localização do erro. Trata-se, portanto, de circunscrever e isolar o problema enquanto tal. A segunda etapa é averiguar, até ao ínfimo pormenor, os momentos que deram origem a passos falhos. Isto é, está em jogo radiografar cada erro de forma precisa, completa, de tal sorte que somente através da remoção do erro alguém pode seguir a pista do caminho do sentido.

\begin{abstract}
O efeito de uma analogia falsa integrada na linguagem: ela significa uma luta permanente e uma inquietação (como que um estímulo permanente). É como quando uma coisa à distância parece ser uma pessoa, porque nós não percebemos certos aspectos e, de perto, vemos que é um toco de árvore. Mal nos afastamos um pouco e perdemos de vista as explicações, então parece-nos uma forma, se em seguida olhamos mais de perto, então vemos uma outra, agora afastamo-nos novamente, etc. (TS 213, $409=$ Cf. BT, $\S 87$, p. 302)
\end{abstract}

A passagem que acabamos de citar põe em evidência uma novidade: não se trata somente de localizar e remover as comparações falsas e imprecisas integradas na linguagem corrente através do seu uso indevido, mas também de dar conta de certa dificuldade inerente ao ser humano em usar a própria linguagem. Wittgenstein expressa esta dificuldade através de uma metáfora aplicada ao olhar que põe em evidência as diferentes perspectivas de um objeto, de forma alternada, ao aproximar-me e ao afastar-me dele.

Com este exemplo, Wittgenstein pretende sublinhar o seguinte: sempre que há um afastamento do objeto da percepção há uma perda de acuidade e de nitidez relativamente aos pormenores e, em contrapartida, sempre que há uma aproximação ao objeto percebido se ganha nitidez quanto aos pormenores. Por outras palavras: Wittgenstein parece estar apenas interessado em chamar a atenção para um único aspecto: ganhamos leitura visual dos objetos com a aproximação e a perdemos com o afastamento.

No entanto, aquilo que está implicado, em termos meramente perceptivos, no movimento de aproximação e afastamento de um objeto diz respeito a um leque de fenômenos muito mais vasto e complexo, pois além do ganho e perda de leitura dos pormenores que ocorre por ocasião do movimento alternado de aproximação e afastamento do objeto, o mesmo movimento envolve outros aspectos para os quais Wittgenstein não quer chamar a atenção.

Dessa forma, no movimento de aproximação é evidente que ganhamos acuidade e nitidez nos detalhes, mas esse ganho faz-se à custa de várias perdas. Isto é, perdemos abrangência espacial, perdemos ângulo de enquadramento no qual o objeto se inclui como um entre vários 
constituintes do campo visual. Por outro lado, o mesmo movimento de aproximação ao objeto da percepção significa o tal ganho anteriormente referido em relação aos pormenores, mas esse ganho quer dizer que a aproximação ao objeto tem um limite. Se a aproximação for demasiada, isto é, se encostar os olhos no objeto perceptivo, não se vê senão uma mancha indiferenciada e totalmente desfocada.

Portanto, nesta situação, vemo-nos obrigados a reconhecer que precisamos de certo afastamento para haver focagem, leitura visual. Com efeito, as várias vertentes a partir das quais o simples fenômeno do movimento alternado de aproximação e afastamento é passível de ser interpretado não estão contempladas no exemplo de Wittgenstein, nem nós fizemos referência a todas elas. Quisemos apenas chamar a atenção para o exemplo direcionado por Wittgenstein quanto ao efeito do uso de uma analogia.

\section{A atividade destruidora}

A atividade filosófica de Wittgenstein é terapêutica e analógica. De acordo com esta atividade, uma analogia perfeitamente ajustada tem um efeito completamente diferente de uma analogia falsa. Enquanto a analogia correta produz um acordo com as coisas, a analogia falsa produz um desacordo e como que nos desvia disso que procura manifestar. Neste segundo caso, o sujeito cai em uma espécie de intranquilidade e desorientação, uma das fontes da inquietação filosófica. É neste contexto que entra em jogo o conceito de palavra libertadora ("das erlösende Wort"). Alcançar esta palavra significa, antes de tudo, conquistar um ponto de vista adequado acerca de um problema que até o presente momento se mantinha prisioneiro de uma analogia incorreta ou falsa. Aliás, os problemas filosóficos são, quase sempre, sinônimos de desorientação. Deste modo, a palavra libertadora vem libertar do tormento o sujeito em estado problemático de que brota a pergunta filosófica.

O filósofo procura alcançar a palavra libertadora, que é a palavra que, por fim, nos permite apreender aquilo que até agora, inapreensível, sempre incomodou a nossa consciência. (É como quando se tem um cabelo na língua: sente-se, mas não se é capaz de apanhar/agarrar e por isso de se ver livre dele). $(\text { TS } 213,409=\text { Cf. BT, } \S 87, \text { p. 302) })^{18}$

\footnotetext{
18 Esse tema da "palavra libertadora" tem um tratamento relativamente escasso, mas desempenha um papel fundamental nas considerações metodológica de Wittgenstein, quanto à satisfação do confronto com os problemas filosóficos que com ele se pretende alcançar. As três primeiras ocorrências são registradas nos GT em 17/10/1914, p. 72, em 21/11/1914, pp. 96-98 e em 22/11/1914, p. 98. Há outra ocorrência mais tarde nos TB 1914-16, em 3/6/1915 e em uma carta a Ludwig von Ficker: BLF, 18, de 24/7/1915, p. 28.
} 
Uma tarefa importante reservada ao filosofar consiste, paradoxalmente, não na solução, mas antes na dissolução dos problemas filosóficos. Isso significa que não se procura responder de forma positiva a uma questão, pelo contrário, através de uma análise minuciosa anula-se a pergunta e o problema desfaz-se na anulação ${ }^{19}$. O processo argumentativo, tal como é tradicionalmente entendido, não passa de uma miragem nos textos de Wittgenstein. Mesmo no BT, em que se menciona que "filosofar é refutar falsos argumentos" (TS 213, $409=$ Cf. BT, $\S 87$, p. 302), a atividade filosófica não se ocupa, segundo Wittgenstein, da refutação argumentativa em sentido tradicional. Pelo contrário, ela procura derruir as evidências que compõe o edifício sobre o qual assenta a atitude natural diante da linguagem e, por consequência, diante do mundo.

Neste aspecto, tanto quanto nos é dado perceber, a sua posição não se restringe à destruição e demolição maciça como se nada ocupasse o lugar daquilo que é refutado, demolido, destruído. Destruir falsidades e não colocar nenhuma alternativa em seu lugar pode parecer, aos olhos de alguns intérpretes de Wittgenstein, não passar de uma tarefa inconsequente e gratuita. Todavia, a finalidade de Wittgenstein consiste, além de destruir, em limpar o terreno da linguagem e curar o sujeito dos mal-entendidos aos quais ela constantemente conduz. Trata-se, por isso, de eliminar "conhecimentos" puramente virtuais que ocupavam o centro, como se

\begin{abstract}
Além destas ocorrências e da citação supra do BT [TS 213], não conhecemos outras nos trabalhos publicados de Wittgenstein. Porém, encontramos diversas passagens do espólio onde a expressão aparece, mas como um decalque da citação supracitada do BT. Assim, as versões do MS 107, 114, do MS 110, 17, do MS 142, 109-110, do TS 211, 18, do TS 212, 1115 e 1116, do TS 220, 83, do TS 238, 11 e do TS 239, 84 apenas divergem em aspectos de pontuação, oração ou omissão de exemplos. Portanto, todas as versões do Nachlass, com ligeiras variações características do método filosófico de Wittgenstein, giram em torno da mesma formulação.

Há um artigo que se ocupa deste problema e nos convida a ler as passagens referidas acima acerca da palavra libertadora em estreita ligação com o pensamento religioso. Cf. BOERO, 1993, p. 383-389. Outra abordagem deste termo o interpreta com um propósito ético, como é o caso de Ostrow. Cf. OSTROW, 2002, pp. 125-135. Ver, também, TANESINI, 2004, pp. 39-41. Se estes são os contextos em que a expressão é utilizada, não nos parecem ser estes os sentidos exclusivos, pois para nós, a palavra libertadora diz respeito à solução de um problema filosófico difícil e, em última análise, aproxima-se da noção de "visão perspícua" com o sentido de uma visão de adequação expressivamente total, de um ponto de vista totalmente capacitado para o conhecimento da realidade e capaz de trazer paz a quem a pronuncia. Confirma esta posição, a versão do MS 107, 114: "A tarefa da filosofia é encontrar a palavra libertadora. A palavra libertadora é a solução de um problema filosófico."

${ }^{19}$ São várias e sugestivas as metáforas desta aniquilação da pergunta. Desde compará-la a um torrão de açúcar que se dissolve na água até a proposta de destruir castelos de areia que aparentavam ser construções da maior importância filosófica. Como, por exemplo, TS 213, $411=$ Cf. BT, $\S 88$, p. 304; TS 213, 414-415 = Cf. BT, $\S 89,306$; TS 227b, 87 = Cf. PU, $\S 118$.
\end{abstract}


fossem os pilares, de uma forma de captar a realidade e, mediante este procedimento, abrir caminho a uma nova forma de ver e perceber as coisas do mundo. Assim, indica-se a idéia de uma tarefa essencialmente destrutiva da atividade filosófica.

Os pensamentos que compõem o parágrafo 88 retomam e especificam, na íntegra, questões levantadas no parágrafo anterior. A crítica da linguagem constitui o tema central. A tarefa filosófica consiste em combater o fascínio que tais questões exercem constantemente. Para usar o vocabulário wittgensteiniano, as palavras têm de ser reconduzidas do seu sentido metafísico ao sentido trivial e familiar que os falantes lhes atribuem no dia a dia. Não surpreende, pois, que a tarefa filosófica realizada segundo este princípio transmita, mais uma vez, uma imagem destruidora:

\footnotetext{
De onde é que [esta] consideração retira a sua importância, uma vez que parece limitar-se a destruir tudo o que é interessante, isto é, tudo o que é grande e importante? (Como que todas as construções; deixando apenas pedregulhos e entulhos). (TS 213, $411=$ Cf. BT, §88, p. 304; TS 227b, $87=$ Cf. PU, §118)
}

Esta onda de destruição atinge proporções gigantescas desde os primeiros escritos de Wittgenstein e produz efeitos pela obra afora. E, como foi dito no capítulo anterior, a tradição filosófica constitui o seu alvo favorito. De acordo com Wittgenstein, a herança dos problemas filosóficos trouxe consigo, mais do que um ganho ou uma riqueza estabilizada, uma necessidade urgente de revisão.

O empreendimento filosófico wittgensteiniano assume, em vários momentos, um aspecto devastador sem paralelo, uma vez que estabelece uma alteração radical no método adotado e, como consequência, os resultados também são inteiramente outros. A primeira impressão é a de que não fica pedra sobre pedra: por força da aplicação metodológica assinalada, parece que só restam ruínas e entulhos. No entanto, o resultado desolador deste procedimento deve atribuir-se ao fato de a linguagem ser o centro de todas as disputas.

Com efeito, não se pode reduzir a investida filosófica a um ataque gratuito à tradição. Pelo contrário, o que Wittgenstein revela é de uma importância capital para os seus propósitos. Os problemas herdados por meio da tradição filosófica ocidental chegaram, até o presente, impregnados de vícios de análises e perspectivas em virtude dos quais a imagem dela surge adornada de predicados que não lhe convêm: a aparência grandiosa, o caráter profundo, a idolatria das questões metafísicas. Uma das prioridades da filosofia de Wittgenstein é justamente descer ao plano do quotidiano: "(Tudo o que a filosofia pode fazer é destruir ídolos. E isso significa não 
criar nenhum novo - designadamente na 'ausência de um ídolo'.)" (TS 213, $413=$ Cf. BT, $\S 88$, p. 305) ${ }^{20}$

Portanto, a luta contra as formas enganadoras da linguagem trava-se no interior da sua própria esfera. Destruir ídolos faz parte da tarefa de limpar a linguagem de uma série de idéias culturalmente transmitidas e raramente questionadas. Essa herança contém, ao lado da fixação de certo saber, uma inibição da novidade.

\section{As condições lingüísticas do pensar próprio}

No parágrafo 89 do BT Wittgenstein tece algumas considerações sobre o que significa uma pergunta filosófica, e um dos aspectos que ele foca com mais insistência é o de que a pergunta resulta, inevitavelmente, de uma falta de clareza intelectual por parte de quem questiona. Quer dizer, quem questiona não sabe a função exata daquilo que é questionado.

Assim, a pergunta nasce de um embaraço, de um estar em dificuldade e por procurar de todas as maneiras sair dela. Para recuperar o modo de formulação transmitido pela tradição a pergunta origina-se de uma dificuldade, traduz sempre um grau de desorientação do sujeito que a faz e, ao mesmo tempo, dirije-se já a um alvo, e não é absolutamente indeterminado, desconhecido e inocente. Ela ilustra o movimento em direção a algo que já se detém parcialmente, do qual já se alcançou uma informação, mas que ainda é uma informação obscura, insegura e incompleta. $\mathrm{O}$ ato de perguntar já indica a direção a tomar, já persegue, de um modo que não se afirma com completo esclarecimento, o objeto da sua procura.

Mesmo a pergunta clássica, aparentemente inofensiva, da definição do conceito, de "o que é isto ou aquilo", manifesta a atitude de estar em apuros relativamente ao objeto questionado. Isto é, a pergunta emerge do horizonte da dúvida e a sua tendência interrogativa tem em vista atingir um horizonte de maior clareza acerca do que é perguntado. Assim, a clareza que a pergunta almeja consegue-se, de acordo com o BT, através de uma nova ordenação dos conceitos em virtude da qual cada um passa a ocupar o lugar que lhe compete: "O problema filosófico é uma consciência da desordem nos nossos conceitos e deve superar-se pelo ordenar dos mesmos" (TS 213, 421 = Cf. BT, §89, p. 309). Quer dizer, a pergunta dá expressão a um desconforto intelectual. Esse desconforto tem a sua origem no fato de nunca se ter conferido um significado preciso a esse conceito ou de se the ter atribuído um significado que de todo não lhe pertence.

${ }^{20}$ A constante luta de Wittgenstein contra toda forma de ilusão filosófica, e a efetiva destruição, encontram eco em alguns de seus textos, como, por exemplo, DBT, 1930-1937, 7/2/1931, p. 39 e em MS 153a, 35r = Cf. VB, p. 13. 
Portanto, a dificuldade reside na linguagem. No momento em que se consegue adequar a palavra à função que lhe é pedida, desaparece o desconforto e a inquietação que o ato de perguntar, em Filosofia, costuma provocar. Ao desaparecer a inquietação originada pelo desajustamento que a pergunta ilustra, dissipa-se a pergunta, ela anula-se a si própria, e, na verdade, essa é a resposta que satisfaz. À luz do novo sistema onde o conceito foi integrado, a questão perde o impulso interrogativo que a animava. Perde, por assim dizer, a sua problematicidade. Por isso, Wittgenstein não dá uma resposta às questões filosóficas. Pelo contrário, estabelece a falta de fundamento da pergunta e neutraliza-a desse modo. Wittgenstein reconhece que, à primeira vista, este procedimento deixa o leitor filosófico perplexo e insatisfeito, mas é um preconceito que nos leva constantemente a continuar no momento em que é indispensável parar. ${ }^{21}$

No que tange à inquietação filosófica, o emprego de metáforas extraordinariamente sugestivas nos vários exemplos de Wittgenstein é surpreendente e tem um forte efeito de persuasão como se o poder da imagem "metafórica" valesse por mil palavras. Um primeiro exemplo disso diz o seguinte:

\begin{abstract}
(A quietação particular que ocorre quando conseguimos pôr outros casos semelhantes ao lado de um caso que tínhamos por único ocorre sempre de novo nas nossas investigações quando mostramos que uma palavra não tem apenas um significado (ou não tem apenas dois), antes é usada com cinco ou seis acepções diferentes.)

Os problemas filosóficos podem comparar-se com os cofres em código que são abertos através da formação de uma determinada palavra ou de um determinado número, de tal modo que nenhuma força é capaz de abrir a porta, antes, de se achar justamente esta palavra e, uma vez achada, qualquer criança é capaz de abri-la. (TS 213, 416 = Cf. BT, \$89, p. 307)
\end{abstract}

Ou seja, trata-se de encontrar casos particulares que, ao primeiro olhar, não tinham nada em comum, mas que se bem vistos partilham de uma característica qualquer que permite agrupá-los sob a alçada de um mesmo conceito ou da mesma regra. Aquilo que impedia de compreender o singular era, precisamente, a impossibilidade de agrupá-lo com outros e de integrá-lo em uma classe a que pertencia. Havia um aspecto que permanecia escondido

\footnotetext{
21 Esta questão encontra a sua formulação mais convincente nestas duas passagens: a primeira diz o seguinte: “Aqui é avassaladora a tentação de dizer ainda algo quando já tudo foi descrito. - de onde provém esta pulsão? Que analogia, que falsa interpretação a gera?”. (MS 129, 127 = Cf. Z, §313). E a segunda: "Deparamos aqui com um fenômeno peculiar e característico [que ocorre] nas investigações filosóficas: a dificuldade - poderia dizer - não é encontrar a solução, mas reconhecer como solução aquilo que parece que seria somente um estado preliminar dela. 'Já dissemos tudo - não é algo que resulta disto, mas justamente isto é que é a solução!' [...]. A dificuldade aqui é parar.” (MS 115, p. 61 = Cf. Z, § 314)
} 
e ignorado. Portanto, a metáfora que Wittgenstein encontra para ilustrar este caso é a da formulação de uma palavra ou de uma série de números que perfazem um código ou uma chave secreta para a abertura da porta de um cofre a qual nenhuma violência consegue abri-lo.

O segundo exemplo afirma o seguinte:

Tal como eu exerço a filosofia, toda a sua tarefa é formular a expressão de tal modo que determinadas inquietações/problemas desapareçam (Hertz.). Se tenho razão, então os problemas filosóficos, ao contrário de todos os outros, têm efetivamente que se dissolver sem deixar resíduo. Quando eu digo: aqui estamos nos limites da linguagem, isso parece sempre como se aqui fosse necessária uma resignação, quando, pelo contrário, o que entra em cena é uma satisfação plena, dado que não resta nenhuma pergunta. Os problemas são dissolvidos no sentido próprio [do termo] - como um torrão de açúcar na água. (TS 213, 421 = Cf. BT, §89, p. 310)

Como a citação acima explicita, um problema filosófico significa, nos textos do BT (assim como nas PU), estar literalmente desorientado e perdido (TS 213, $421=$ Cf. BT, §89, p. 310; TS 227b, 88-89 = Cf. PU, $\S 123)$. E esta desorientação pode curar-se por duas vias diferentes. A primeira consiste na reordenação dos conceitos: atribuir-lhes corretamente o seu lugar gramatical na linguagem. E a segunda em resolver os problemas filosóficos de uma forma análoga. Trata-se também de uma conformação entre os objetos e o modo de enunciá-los, mas aparentemente, vai além disso. Como foi dito na penúltima citação acima, a superação da incomodidade é comparável à abertura de um cofre. Quer dizer, é preciso descobrir qual a palavra, chave ou senha que tenha o poder de abri-lo sem forçá-lo. Por conseguinte, o filósofo tem de encontrar para cada caso a senha ou a chave que lhe convém. A fechadura do cofre constitui um problema que desaparece ao encontrar-se a palavra adequada com a qual se abre.

Há, no entanto, dois obstáculos que dificultam constantemente que o ponto de vista cure a inquietação cujas raízes são os sentimentos de confusão e obscuridade a que se pode estar exposto ao fazer uma pergunta. Os obstáculos são a ausência de uma apresentação panorâmica da linguagem e o falso domínio baseados no descuido para com as realidades mais próximas e familiares ao ponto de vista habitual.

Para Wittgenstein, a impossibilidade de uma apresentação ou visão panorâmica da linguagem dificulta seriamente a obtenção de clareza e compreensão acerca dos problemas que lhe dizem respeito e da caracterização da tarefa da Filosofia como sendo crítica da linguagem, porque a complexidade da natureza da linguagem não se expõe, por si só, ao falarmos ou escrevermos, nem se esta for considerada de um ponto de vista meramente teórico, prático ou na consideração conjugada de ambos. 
Somente através de uma demorada análise pode-se descobrir e clarificar a complexidade de articulações que as palavras admitem entre si. Assim, a hipótese de uma visão panorâmica da linguagem humana aproxima-se de uma possibilidade porventura impossível de satisfazer, quer já pela própria natureza do ponto de vista humano que só consegue focar um âmbito restrito de cada vez, de sorte que não abrange mais do que traços, fragmentos do que há da totalidade da linguagem; quer já pelo fato de a linguagem ser um organismo vivo e de, a cada instante que passa, poder perder usos ou ganhar conjugações imprevistas. No entanto, se o ponto de vista conseguisse alcançar efetivamente uma visão panorâmica, ela equivaleria a qualquer coisa como abranger de uma só vez o âmbito total das possibilidades de relação do vocabulário que compõe uma língua. $\mathrm{Ou}$ seja, nenhuma ocorrência ou possibilidade de conjugação escaparia a esse ponto de vista. $^{22}$

Logo a seguir, Wittgenstein aponta um segundo obstáculo, não menos importante, que está incrustrado no cerne do próprio ponto de vista habitual. O olhar humano tem uma espécie de certeza de domínio e de transparência de saber com relação à realidade próxima, o que só raramente lhe permite referir-se à mesma como algo apenas aparente, virtual. A familiaridade e a proximidade das coisas constituem o maior obstáculo a uma efetiva compreensão do que são e daquilo que com elas se passa. Deste modo, não surpreende que Wittgenstein registre uma série de pensamentos curtos dedicados a este tema e dos quais citamos um: "Os aspectos filosoficamente mais importantes das coisas/da linguagem estão escondidos pela sua simplicidade e cotidianeidade. (Não se pode notar isso, porque se tem sempre (à vista) diante dos olhos)." (TS 213, $419=$ Cf. BT, §89, p. 419)

Contudo, a revelação mais surpreendente deste parágrafo 89 produzse na última frase. Ela surge como requisito incontornável para solucionar uma série de dificuldades apontadas até então. As várias caracterizações do estado de inquietação e desorientação em que o sujeito se encontra, ao fazer perguntas filosóficas, formam o diagnóstico. O recurso que Wittgenstein preconiza para curar as debilidades que afetam o entendimento em si mesmo parece simples, claro e pacífico, quase correspondendo mesmo a um truísmo. Mas, proposto por Wittgenstein, o princípio ou o recurso

\footnotetext{
${ }^{22}$ A presente exposição considera a problematicidade inerente à tradução do conceito “übersichtlichen Darstellung” e suas variantes. Todavia, ao longo do trabalho notar-se-á a preferência pela versão "apresentação perspícua" entendida como substituindo o termo "apresentação panorâmica" e abrangendo os termos "apresentação sinóptica", "apresentação clara" e "apresentação ordenada". Trata-se, em todo o caso, de uma visão das partes que remete a um ganho de nitidez e precisão do todo, e do todo em relação às partes que constituem o campo visual. Este conceito está disperso por vários textos do Nachlass de Wittgenstein os quais são citados ao longo do trabalho, como, por exemplo: TS 213, 417 = Cf. BT, §89, 417, p. 307; MS 114, 190 e TS 209, 1 = Cf. PB, I, §2, p. 5; TS 227b, $8=$ Cf. PU, §5; TS 227b, 77 = Cf. PU §92; TS 227b, p. 88 = Cf. PU, §122.
}

Wittgenstein e a tradição filosófica: aspectos metodológicos - Gilberto Ferreira de Souza 
metodológico em questão causa certo espanto e estranheza: "As pessoas que não têm necessidade de transparência na sua argumentação estão perdidas para a filosofia." (TS 213, 419 = Cf. BT, §89, p. 419)

Esta máxima ou princípio metodológico surpreende o leitor. Em primeiro lugar, por Wittgenstein referir-se ao processo argumentativo do qual os seus textos se divorciam quase que completamente, e em segundo lugar por fazer um apelo à necessidade de uma transparência que muitos leitores podem ter a impressão de estar muito longe de caracterizar os seus próprios textos. Contudo, o juízo proferido não podia ser mais radical, dogmático e contundente: quem não observar aqueles dois requesitos está, desde o início, condenado ao fracasso em Filosofia. Ninguém ousaria discordar do conteúdo desta máxima, mas se a projetarmos sobre os textos de Wittgenstein ela parece perder, em vários momentos, o seu valor operatório.

As anotações que compõem o parágrafo 90 caracterizam-se por todos estes ingredientes juntos. $\mathrm{O}$ que estava em jogo no parágrafo anterior era elucidar propriedades específicas do ponto de vista habitual que dificultavam uma efetiva apreensão dos objetos no plano das realidades próximas ao sujeito, ao passo que neste parágrafo está em jogo localizar e se possível erradicar as armadilhas que impedem o ponto de vista de alcançar com precisão e acuidade o objeto investigado, isto porque as armadilhas significam muitos e diversos perigos, como as maneiras absurdas de pensar. Não pense, porém, que elas são colocadas no terreno da linguagem por um espírito maligno qualquer, exterior a ela. Não. As armadilhas são os frutos da desatenção do ponto de vista quanto ao emprego da linguagem e só um enorme esforço de focagem e atenção logra localizá-las. Por conseguinte, o filósofo está investido de uma dupla tarefa: localizá-las para poder evitá-las ou, se for o caso, para poder anulá-las na sua eficácia e, simultaneamente, manter um nível de vigilância e prudência para não se cair, de novo, no engodo delas. Deste modo, a atividade filosófica tem uma complexidade variável conforme a situação em que se encontra o ponto de vista que a leva a cabo. Quanto maior for a confusão e a desorientação do ponto de vista no interior da linguagem, maior será a sua necessidade de revisão. Conforme a gravidade da doença de que sofre, assim se torna conveniente escolher a dosagem terapêutica adequada.

O ser humano está preso às armadilhas da linguagem e isso por duas razões diferentes. Em primeiro lugar porque o humano vive na linguagem, vive mergulhado na sua língua materna de tal modo que ela possibilita e propicia uma determinada conformação do mundo que se exprime em termos gestuais ou escritos e não em termos orais, e a língua que cada um de nós viu nascer assenta em determinadas formas matrizes e pilares que a suportam e que lhes permitem ser o que é. Isto é, a língua materna desenhou um percurso, tem uma história que a identifica e que está em constante mutação. O sujeito, por sua vez, nasce no seio dessa história e a agarra para 
si. Deste modo, a linguagem dá expressão e privilegia certas matrizes do pensar em vez de outras por circunstâncias internas e externas ao próprio fenômeno linguístico. Os sujeitos tendem, instintivamente, a utilizar e privilegar certas matrizes em detrimento de outras possíveis. E as matrizes de cada língua formam uma rede de possibilidades quase infinita que os falantes têm ao seu dispor. No entanto, nessa rede quase infinita de caminhos, cada escolha leva a consequências e implicações específicas.

\begin{abstract}
As pessoas estão profundamente incrustradas em confusões filosóficas, isto é, confusões gramaticais, e libertá-las delas pressupõe arrancá-las das ligações colossalmente diversificadas nas quais estão presas. Por assim dizer, tem de se reagrupar toda a sua linguagem, mas esta linguagem formou-se deste modo, porque as pessoas tinham - e têm - a inclinação para pensar assim. Por isso, o arranque só funciona para aqueles que vivem em uma instintiva rebelião contra (insatisfação com) a linguagem. Não para aqueles que, segundo todo o seu instinto, vivem no rebanho que criou esta linguagem enquanto sua autêntica expressão. (TS 213, $423=$ Cf. BT, §90, p. 311)
\end{abstract}

Contudo pode-se viver toda a vida no seio do rebanho da língua materna como se fosse o seu ambiente natural e próprio sem alguma vez se suspeitar sequer de que as confusões e ardis gramaticais são os verdadeiros grilhões que prendem o sujeito a essa situação. Deste modo, à luz do parágrafo 90 do BT, uma parcela importante do trabalho filosófico consiste em avaliar a posição em que se está, em tomar conciência da posição que se ocupa, de tal modo que se faça um diagnóstico das condições linguísticas do próprio pensar.

Nesse sentido, a filosofia de Wittgenstein "apenas" reclama transparência e clareza do que está aí e acalma em si o desejo de alcançar novas e grandiosas descobertas do que quer que seja ou de alcançar a totalidade das possibilidades. Aspira apresentar o trivial e quotidiano enquanto tal, despido de falsas metafísicas.

A segunda razão que prende o ser humano à linguagem tem a ver com uma concepção falsa da sua capacidade de configuração ${ }^{23}$. Questões que revelam um impulso da razão: "Os resultados da filosofia são a descoberta de um absurdo simples qualquer, e as mossas, que o entendimento arranjou ao bater contra os limites da linguagem. Elas, as

\footnotetext{
${ }^{23}$ Este termo parece ter origem na fenomenologia de Husserl, foi empregue na Gestaltterapia por Goodman e significa a tentativa de aproximação ou construção de uma "totalidade autêntica", “objetiva" e livre do foro "intencional” (Cf. D’ACRI, G; LIMA, P; ORGLER, S., 2007, pp. 48-50). Esse parece ser exatamente o sentido metodológico que atribuímos às observações de Wittgenstein. Esta maneira de olhar o todo dinâmico deve procurar ser o mais autêntico possível.
} 
mossas, fazem-nos reconhecer o valor daquela descoberta." (TS 213, $425=$ Cf. BT, §90, p. 311)

Um dos resultados palpáveis da filosofia devia ser, então, esta simples tomada de consciência, a saber, a de parar ou de frear todo aquele ímpeto filosófico, na acepção tradicional do termo, que manifesta o desejo de ultrapassar os limites do mundo.

Voltando às análises do BT, Wittgenstein insurge-se contra o fato de uma grande parte dos problemas filosóficos brotar de um plano meramente especulativo e não de um plano prático ou factual. Isso acontece pelo fato de o filósofo se deixar encantar por comparações ou por associações linguísticas que contradizem o contato que naturalmente se tem com a realidade.

O parágrafo 91 do BT está a combater justamente o símile de Heráclito de que "tudo flui". Wittgenstein, por sua vez, afirma que, pelo contrário, nunca é possível considerarmos duas imagens simultâneas do mesmo fenômeno, uma com a qual contatamos e outra que fosse apenas uma sombra que escapa e se enconde constantemente sob a superfície dos fenômenos. A nossa apreensão do mundo dá-se no universo da representação (e não no da coisa em si) a qual pressupõe uma estrutura espaço-temporal, e sem a qual a representação não seria possível. Por outro lado, a nossa apreensão do mundo exterior acontece a partir de um conjunto de características peculiares do aparelho cognitivo do ser humano. Nesse sentido, a visão humana pode significar por contraposição a outras formas de apreensão visual, existentes ou imaginárias, para justificar uma apreensão insuficiente das realidades do mundo. Por exemplo, é difícil imaginar o que seja um olhar sem perspectiva ou um olhar que abranja todas as amplitudes ou ângulos possíveis.

Ora, Wittgenstein acredita que o que está à vista é tudo, precisamos apenas revelar isso que esteve sempre diante de nós e que, em virtude de um adormecimento quase permanente da nossa maneira de captar a realidade, se mantém como que oculto. O que precisa de revisão é, pura e simplesmente, a nossa maneira de ver as coisas.

Cada idéia que compõe o parágrafo 92 chama a atenção para a atitude inconveniente que os homens têm diante de tais problemas e aconselha uma revisão profunda do método filosófico. Sem esta revisão, onde cada um dos vários passos da resolução de um problema é organizado com critérios bem definidos, não é possível obter resultados seguros e pacíficos no universo polêmico da filosofia.

(A maioria dos homens, quando tem de levar a cabo uma investigação filosófica, fá-lo como alguém que, com extremo nervosismo, procura um objeto em uma gaveta.

Atira papéis para fora da gaveta - aquilo que procura pode estar entre eles - e folheia entre os restantes de forma precipitada e pouco exata. Atira de novo alguns papéis para 
dentro da gaveta, mistura-os com os outros, etc. Pode-se-lhe então dizer assim: para, se procuras assim, não posso ajudá-lo a procurar. Em primeiro lugar, tens de começar no mais completo sossego a investigar metodicamente um papel a seguir ao outro, então também estou pronto a procurar contigo e a regular-me também por ti no que concerne ao método). (TS 213, 432 = Cf. BT, §92, p. 316)

\section{Considerações finais}

A partir destas observações acima expostas, podemos refazer as seguintes afirmações:

A relação de Wittgenstein com a tradição filosófica se caracteriza metodologicamente por um confronto contundente. E este confronto com a tradição não se acentua por um conhecimento apurado e nem por uma ignorância, mas por certa indiferença quanto à sua contribuição por si só para o pensamento autônomo.

A principal dificuldade da filosofia, estreitamente relacionada às resistências da vontade, é estar diante dos conceitos sem pré-conceitos. E diante desta dificuldade, quem se dispõe a filosofar deve atentar-se, defrontar-se e superá-la.

A recuperação do papel que a tradição filosófica pode desempenhar para o pensamento próprio deve emergir em um terreno livre de intromissões alheias, dos pré-conceitos assim como de um confronto genuíno e original com os problemas atuais.

Enfim, a característica marcante do método filosófico de Wittgenstein é a efetivação da atividade terapêutica destruidora dos vícios, adornos e ídolos herdados da tradição. E somente uma averiguação das condições lingüísticas do pensamento vai permitir a obtenção de resultados seguros e pacíficos no universo polêmico da filosofia. 


\section{Lista de abreviaturas}

BGM Bemerkungen über die Grundlagen der Mathematik

BLF Briefean Ludwig von Ficker

BPP II Bemerkungen über die Philosophie der Psychologie. v. 2

BT The Big Typescript, TS. 213

DBT Denkbewegungen, Tagebücher 1930-32/ 1936-37

GT Geheime Tagebücher 1914-1916

LPE Wittgenstein's Notes for Lectures on Private Experience and Sense Data

LSPP I Letzte Schriften über die Philosophie der Psychologie. v. 1

PB Philosophische Bemerkungen

PG Philosophische Grammatik

PU Philosophische Untersuchungen

TB Notebooks, 1914-1916/Tagebücher 1914-1916

TLP Tractatus Logico-Philosophicus

TSL The Science of Logic: an Inquiry into the Principles of Accurate

ÜG Thought and Scient

VB Vermischte Bemerkungen/Culture and Value

WCLD Wittgensteinin Cambridge: Letters and Documents 1911-1951

WN Wittgenstein's Nachlass: The Bergen Electronic Edition

Z Zettel

\section{Referências bibliográficas}

ARISTÓTELES. Metafísica. Livro II, 993a 30-993b. Edición Trilingüe. Madrid: Gredos, 1990.

BOERO, M. Wittgenstein y la "Palabra Redentora". In: Estudios Franciscanos, pp. 406-407, 1993.

D'ACRI, G.; LIMA, P.; ORGLER, S. Dicionário de Gestalt-terapia: Gestaltês. São Paulo: Summus, 2007.

KANT, I. Beantwortung der Frage: Was ist Aufklärung? In: Textos seletos. Petrópolis: Ed. Vozes, pp. 100-117, 1974.

. Resposta à Pergunta: 'O Que é Esclarecimento?' Trad.: Floriano

de Souza Fernandes. Im: Kant, I. Textos Seletos. Org. E. Carneiro Leão. Petrópolis: Vozes, [1784]1974.

[1781]2003.

Crítica da Razão Pura. São Paulo: Editora Martins Fontes, . Reflexionen zur Anthropologie, 1488, v. XV, p. 632. Disponível em: http://www.korpora.org/kant/aa15/. Acesso em 20 de out. de 2013.

OSTROW, M. Tractatus: A Dialectical Interpretation. Cambridge: Cambridge University Press, 2002. 
TANESINI, A. Wittgenstein: A Feminist Interpretation. Cambridge: Polity Press, 2004.

WITTGENSTEIN, L. J. J. Wittgenstein's Nachlass: the Bergen Electronic Edition. Edited by The Wittgenstein Archives at the University of Bergen. Oxford: Oxford University Press, 2000.

. The Science of Logic: an Inquiry into the Principles of Accurate

Thought and Scientific Method by P. Coffey. Cambridge: The Cambridge Review, 853, 1913.

. Tractatus logico-philosophicus. 2. ed. Trad. SANTOS, L. H. L. São

Paulo: EDUSP, 1994.

. Vermischte Bemerkungen/Culture and value. Ed. WRIGHT, G. H.

von; NYMAN, H. 2. ed. with English transl. Oxford: Basil Blackwell, 1980.

. Zettel. Ed. ANSCOMBE, G. E. M. \& WRIGHT, G. H. von. Transl.

ANSCOMBE, G. E. M. Berkeley and Los Angeles: University California Press, 1970.

. Philosophical Investigations/Philosophische Untersuchungen. Ed.

HACKER, P. M. S. \& SCHULTE, J. Transl. ANSCOMBE, G. E. M.;

HACKER, P. M. S. \& SCHULTE, J. 4. ed. Oxford: Wiley-Blackwell, 2009. . The Big Typescript, TS. 213. Ed. LUCKHARDT, C. G.; AUE, M.

German-English scholar's ed. Malden, MA: Blackwell, 2005.

. Denkbewegungen: tagebucher 1930-1932, 1936-1937. (MS 183).

Ed. SOMAVILLA, I. von. Innsbruck: Haymon, 1997.

Philosophical Grammar/Philosophische Grammatik. Ed. RHEES,

R. Transl. KENNY, A. Oxford: Basil Blackwell, 1974.

Philosophical Remarks/Philosophische Bemerkungen. Ed. RHEES,

R. Transl. HARGREAVES, R. Oxford: Basil Blackwell, 1975.

Last writings on the philosophy of psychology/Letzte Schriften über

die Philosophie der Psychologie. v. 1. Ed. WRIGHT, G. H. von; NYMAN, H. Trad. LUCKHARDT, C. G.; AUE, M. Oxford: Basil Blackwell, 1982.

. Wittgenstein's Notes for Lectures on Private Experience and Sense Data. (1936), org. RHEES, R. Philosophical Review, 77 (1968), pp. 275320.

Wittgenstein in Cambridge: letters and documents, 1911-1951. Oxford: Basil Blackwell, 2008.

Remarks on the Philosophy of Psychology/Bemerkungen über die Philosophie der Psychologie. v. 2. Edit. WRIGHT, G. H. von; NYMAN, Heikki. Transl. LUCKHARDT, C.G.; AUE, M. Oxford: Basil Blackwell, 1980.

. Geheime tagebucher, 1914-1916. Herausgegeben und dokumentiert von BAUM, W.; Vorwort von ALBERT, H. 3. Ed. Wien: Turia and Kant, 1992.

Notebooks, 1914-1916/Tagebücher 1914-1916. Ed. WRIGHT, G. H. von; ANSCOMBE, G. E. M. Transl. ANSCOMBE, G. E. M. Index of KLEMKE, E. D. Oxford: Basil Blackwell, 1969. 
. Briefe an Ludwig von Ficker. Ed. WRIGHT, G. H. von; METHLAGL, M. W. Salzburg: Otto Muller, 1969.

. Remarks on the Foundations of Mathematics. Revised edition. Ed.

RHEES, R.; ANSCOMBE, G. E. M. Massachucets, MIT press, 1983.

. On Certainty/Über Gewißheit. Ed. G.E.M. Anscombe and G.H. von

Wright. Transl. Denis Paul and G.E.M. Anscombe. Oxford: Basil Blackwell, 1969.

Autor(a) para correspondência: Gilberto Ferreira de Souza, Universidade Estadual de Campinas, Instituto de Filosofia e Ciências Humanas, R. Cora Coralina, 100, Cidade Universitária, CEP 13083-896, Campinas - SP, Brasil. gilbertosouza_2005@yahoo.com.br 